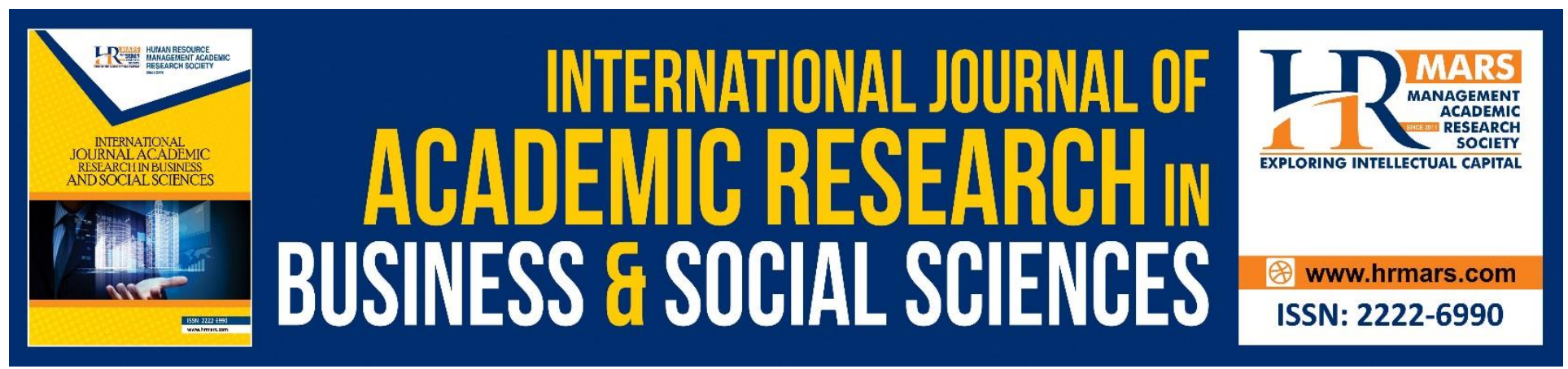

\title{
Analysis of Ethnic Relations in the Medina Charter
}

Zaleha Embong, Nik Yusri Musa, Nazri Muslim, Nurul Iman Ahmad Bukhari

To Link this Article: http://dx.doi.org/10.6007/IJARBSS/v10-i10/7895

DOI:10.6007/IJARBSS/v10-i10/7895

Received: 18 July 2020, Revised: 20 August 2020, Accepted: 15 September 2020

Published Online: 09 October 2020

In-Text Citation: (Embong, Musa, Muslim, \& Bukhari, 2020)

To Cite this Article: Embong, Z., Musa, N. Y., Muslim, N., \& Bukhari, N. I. A. (2020). Analysis of Ethnic Relations in the Medina Charter. International Journal of Academic Research in Business and Social Sciences. 10(10), 2231.

Copyright: (C) 2020 The Author(s)

Published by Human Resource Management Academic Research Society (www.hrmars.com)

This article is published under the Creative Commons Attribution (CC BY 4.0) license. Anyone may reproduce, distribute, translate and create derivative works of this article (for both commercial and non-commercial purposes), subject to full attribution to the original publication and authors. The full terms of this license may be seen

at: http://creativecommons.org/licences/by/4.0/legalcode

Vol. 10, No. 10, 2020, Pg. 22 - 31

http://hrmars.com/index.php/pages/detail/IJARBSS

JOURNAL HOMEPAGE

Full Terms \& Conditions of access and use can be found at http://hrmars.com/index.php/pages/detail/publication-ethics 


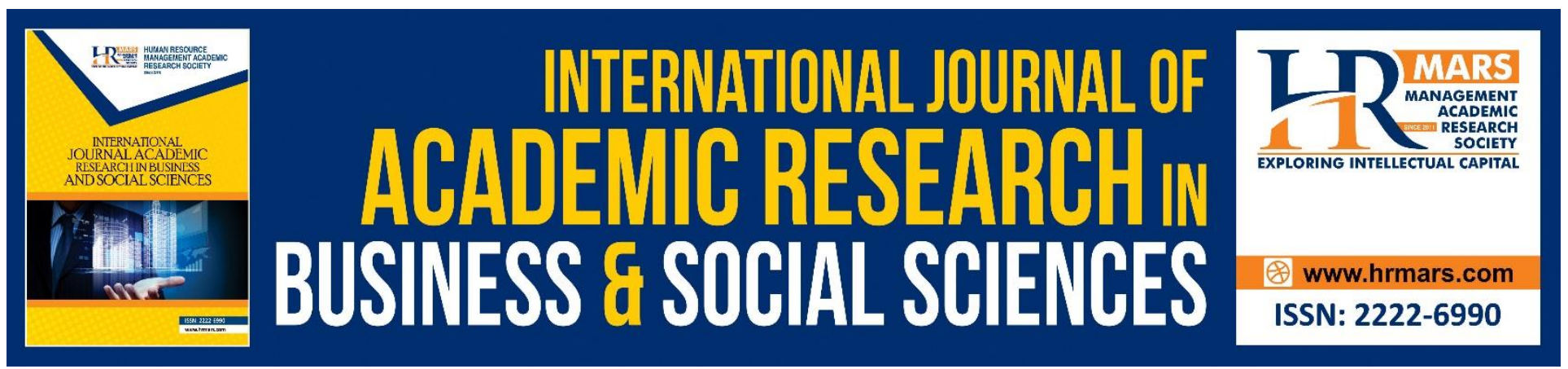

\title{
Analysis of Ethnic Relations in the Medina Charter
}

\author{
Zaleha Embong, Nik Yusri Musa \\ Centre for Language Studies and Generic Development, Universiti Malaysia Kelantan \\ Email: zaleha.e@umk.edu.my,nikyusri@umk.edu.my \\ Nazri Muslim \\ Pusat Citra, Universiti Kebangsaan Malaysia \\ Email: nazrim@ukm.edu.my \\ Nurul Iman Ahmad Bukhari \\ Centre for Language Studies and Generic Development, Universiti Malaysia Kelantan \\ Email: iman@umk.edu.my
}

\begin{abstract}
The creation of human beings of different skin colour and descent, race and language, culture, and customs is not to show arrogance and arrogance between them. Therefore, strong ethnic relations play an essential role in achieving harmony in a multi-ethnic society. Yathrib (the name of Medina before the migration) was located in the Arabian Peninsula as a 'conflict zone' due to the constant disputing and war between the Aus and the Khazraj. The acceptance of the Prophet PBUH as the head of state in Medina enacted the Medina Charter to manage the people of Medina of different races, languages, religions, and cultural customs. The Medina Charter is the first written constitution in the world that successfully governed a multi-ethnic society so that Medina would become a harmonious nation. From this basis, the writing of this article aims to analyse the ethnic relations that existed in the Medina Charter. This article used data collection methods of library research and in-depth interviews. Meanwhile, the content analysis method was used to analyse the data. The findings found that the Prophet Muhammad SAW succeeded in forming close ethnic relations in a multi-ethnic society through the Clauses stipulated in the Medina Charter based on the concepts of tolerance and love.
\end{abstract}

Keywords: Medina Charter, Ethnicity, Islam, Tolerance, Harmony

\section{Introduction}

Allah SWT in His words in surah al-Hujurat verse 13, which means:

"O mankind, indeed We have created you from male and female and made you peoples and tribes that you may know one another. Indeed, the most noble of you in 
INTERNATIONAL JOURNAL OF ACADEMIC RESEARCH IN BUSINESS AND SOCIAL SCIENCES Vol. 10, No. 10, 2020, E-ISSN: 2222-6990 @ 2020 HRMARS

the sight of Allah is the most righteous of you. Indeed, Allah is Knowing and Acquainted.".

According to Hamka (1985: 208), this verse explains that Allah SWT created human beings of various races and tribes with the purpose that human beings may get to know each other. Humans are encouraged to know themselves, such as their origins, ancestry and lineage. Nobleness in the sight of Allah SWT is the nobleness of the heart, kindness, moral, and piety to Allah SWT. This verse was revealed to control the feelings of human beings who consider themselves better than others. This is in line with the view of Ibn Katsir (2004) that the creation of human beings of various nations and tribes is to encourage human beings to know each other. According to Osman (1997), this verse specifically lays the foundation for pluralism in means that human beings avoid conflict and isolation. Meanwhile, human diversity can encourage interaction, cooperation, and complementary relationships.

\section{The Medina Society Before Islam}

Discussions on the Medina society before and after the advent of Islam requires attention due to the significant change of lifestyle between the two time periods. According to Wat (1956), understanding the situation in Medina before Islam is essential in gaining a clear illustration of the times before and after the presence of the Prophet Muhammad PBUH. Before the advent of Islam, disputes and battles were incidences that often occurred, but after the advent of Islam, cooperation became the foundation of social relations among the Medina community (Siddiqi, 1982).

The Arab society before Islam, especially in the Hijjaz Land, had a social structure that governed patterns of behaviour, family relationships, and community groups ( Pulungan, 1993). The Hijjaz Land was a barren district that is part of the Arabian Peninsula located between the Najd Plateau and the Tihamah Beach district. There were three main cities, namely Taif, Mecca, and Medina. Its population consisted of Arabs and Jews. The Arabs lived in Mecca, Medina, and Taif. The Jews also lived in and around Medina. These two groups came from the Semitic race, starting from the Prophet Ibrahim a.s. through his two sons, the Prophet Isaac a.s. and Prophet Ismail a.s. The group of Arabs were descended from Prophet Ismail a.s., while the group of Jews descended from Prophet Isaac a.s. (Guillaume, 2004).

Medina was a small town with an estimated population of 4000 to 5000 people (Abd. Rahman, 1995). Politically, Medina never knew about the state arrangement because the people of Medina at that time depended on the tribal tribes for the sake of their families' lives and security (Rahman, 1992). Their social system was based on the system based on their tribe or group where each tribe protected and defended its members (Al-Hamidi, 2006). There were also the people of Medina who practised nomadic life who were known as the Bedouin Arabs ( Misrawi, 2011; Siddiqi, 1982).

The people of Medina at that period consisted of various races, groups, and tribes such as the Arabs which constituted of the Aus and Khazraj tribes who were immigrants from South Arabia and other Arab tribes who settled in Medina (Ali, 1982). According to Ibn Sa'dal-Baghdadi, in the Aus and Khazraj tribes, there were eight tribes as mentioned in the Medina Charter as well as 33 small groups that were together in the battle of Badr (Watt, 1956). These Arabs adhered to superstitious beliefs, idolatry, and embraced Judaism and Christianity. Meanwhile, among the Jews who accepted the teachings of the Prophet Moses a.s., it is estimated that there were 20 tribes, among them were the well-known tribes, namely Bani Quraizah, Bani Nadhir, and Bani Qainuqa' (Abd. Rahman, 1995 ; Pulungan, 1993). Each group lived in their separate areas, and they rarely interacted with each other 
INTERNATIONAL JOURNAL OF ACADEMIC RESEARCH IN BUSINESS AND SOCIAL SCIENCES Vol. 10, No. 10, 2020, E-ISSN: 2222-6990 @ 2020 HRMARS

in the plural society. Therefore, disputes and fights often occurred among these groups (Misrawi, 2011).

The people of Medina had their respective lifestyles and had social ties that were separated from one group to another. At that time, the relationship between the Arabs and the Jews was not in peaceful terms because both of these groups had intentions in ruling Medina; even the groups within the Jewish tribes were against one another (An-Nadwy, 1983). The Jews dominated and greatly influenced the economic market of Medina. They practised usury and mortgages where mortgages were not only for trade but also involved women and children. The Jews also reaped profits many times over, causing the Arabs to loathe them (Al Mubarakfuri, 2011; Misrawi, 2011; An-Nadwy, 1983).

\section{The Medina Society After Islam}

The arrival of the Prophet PBUH to Medina was on Friday, 12 Rabiulawal of the first year of Hijra equivalent to 27 September of 622 AD, the Prophet PBUH tarried at the house of Abu Ayub al-Ansari (Al Mubarakfuri, 2011; Al -Buthy, 2006). The arrival of the Prophet PBUH was welcomed by the people of Medina, in contrast to the people of Mecca who dominantly opposed the teachings of Islam ( Misrawi, 2011; Rahman, 1992). The Arabs of Medina had a better understanding of the divine and prophetic matters, which may be a result of their association with the Jews who believed in the teachings of the Prophet Moses. Moreover, the Jews often reminded them of the resurrection of a prophet and apostle ( Abd. Rahman, 1995).

This migration changed the population composition of Medina into three large groups, namely the Arabs of Mecca who migrated together with the Prophet PBUH, the Arabs of Medina, and the Jews. The Muslim Mecca Arabs who are immigrants were known as the Muhajirin while the Muslim Arabs of Medina were known as the Ansar. The non-Muslim group consisted of two groups, namely the Jews and the followers of the idolatrous religion known as wathaniyyin (Ahmad, 1973; Abd. Rahman, 1995 ).

\section{Formation of the Medina Charter}

The Medina Charter was written in completion by two Muslim scholars, namely Ibn Ishaq (Died 151H) and Ibn Hisyam (Died 213H) (Izzuddin, 2008: 110). This charter is the first written constitution in the world drafted by the Prophet Muhammad SAW which served as a guide to the plural society in Medina (Watt, 1956; Hamidullah, 1968; Ahmad, 1973; Rahman, 1992; Sidek, 2004; Ibrahim \& ElQasimy, 1985). According to Watt (1956), Peters (1994), and Khairuddin (2007), the Medina Charter is an authentic document and has content that was suitable to the sociological and historical conditions of the time. Guillame (2004) named the Medina Charter as a Friendly Agreement in his book entitled The Life of Muhammad. According to Guillame (2004), this charter emphasised the coexistence between the Muhajirin and the Ansar as well as the Jews. These groups respected each other's religion, protected their property, and had the same obligation in defending Medina. Ibn Ishaq is of the view that (quoted from Peters, 1994: 198):

"And the Apostle of God wrote the document between the Migrants and the Helpers and in it he made peace (wada'a) with the Jews and the pact ('ahada) with them, and he confirmed them according to their religion/law ('ala dinihim) and properties and laid down obligations due to them and imposed obligations upon them". 
INTERNATIONAL JOURNAL OF ACADEMIC RESEARCH IN BUSINESS AND SOCIAL SCIENCES Vol. 10, No. 10, 2020, E-ISSN: 2222-6990 @ 2020 HRMARS

The purpose the Medina Charter enacted is to organise relations and solve problems among the plural society in Medina. Subsequently, the Medina Charter was completed in the first and second years of the Hijrah which contained 47 Clauses and was divided into two parts. The first part constituted Clauses 1 to 23 concerning the Muhajirin and Ansar relations and was completed before the Battle of Badr. Meanwhile, Clauses 24 to 47 are regarding the rights and obligations of the Jews, which was subsequently completed after the Battle of Badr ( Abd. Rahman, 1995, Hussin, 2003). The Medina Charter is the Prophet's PBUH strategy to restructure the political and social system in Medina. Medina needed an orderly administrative system to manage a plural society and strengthen its strength to face various threats.

\section{Analysis of Ethnic Relations in The Medina Charter}

Muslim scholars such as Ibn Abi Rabi', Al-Mawardi, Al-Ghazali, and Ibn Khaldun claimed that an orderly society is needed to create a peaceful and harmonious atmosphere. The endeavour required competent leaders to implement it (Pulungan, 1993; Ibn Khaldun, 1993). The Prophet PBUH effectively managed the conflict in a plural society through the implementation of the Medina Charter. According to Rafiq (2009), this charter is a model manifested from the Qur' an then translated into real life. Therefore, this charter is characterised by a comprehensive government that meets the needs of a plural society. Ab. Majid (2013) stated that:

"The state of Medina was built and founded on the basis of cooperation between races".

The scrupulous foundation was owed to the Prophet PBUH acknowledging both Muslim and nonMuslim communities as citizens through the concept of an ummah (Watt, 1956; Al-Ghazaly, 1997; Izzuddin, 2008). Prophet PBUH placed the concept of ummah in the following Clauses:

Clause 2:

"They shall constitute a separate political unit (Ummah) as distinguished from all the people (of the world)".

Clause 25:

"And the Jews of Bani 'Auf shall be considered as one political community (Ummah) along with the believers - for the Jews their religion, and for the Muslims theirs, be one client or patron. He, however, who is guilty of oppression or breach of treaty, shall suffer the resultant trouble as also his family, but no one besides".

Clauses 25 to 34, the Jewish tribes are mentioned one by one to explain their position as one ummah together with the Muslim community. According to Al-Buti (1997), the implementation of the ummah succeeded in eliminating the caste system, which had damaged the societal system. Ibrahim and ElQasimy (1985) stated that the Medina Charter recognises the Jews as citizens as long as they perform their responsibilities. However, there were three main tribes of Jews, namely the Bani Quraizah, the Bani Nadhir and the Bani Qainuqa' who violated the treaty and were banished from Medina. The Bani Qainuqa' committed the first betrayal towards the Muslim community and violated the terms of the agreement until the cooperation relationship was terminated. Ab. Majid stated:

"If the Jews did not apostatise and were not treacherous, the agreement would have continued".

Therefore, the Prophet PBUH made the community of Medina as one ummah so that the community respected each other, was tolerant and was responsible for maintaining the harmony of Medina. The implementation of this concept of ummah also built a relationship of love and justice in the society and proved that the Prophet PBUH practised the principles of tolerance, love, respect, justice, and 
INTERNATIONAL JOURNAL OF ACADEMIC RESEARCH IN BUSINESS AND SOCIAL SCIENCES

Vol. 10, No. 10, 2020, E-ISSN: 2222-6990 @ 2020 HRMARS

responsibility in the Medina Charter. These principles will be discussed in detail to depict the success of Prophet PBUH in forming social cohesion in the plural society of Medina.

\section{Principle of Tolerance}

The principle of tolerance is discussed a lot in the Qur'an both implicitly and explicitly. The Qur'an explains the principle of tolerance for human beings to accept differences, respect each other, and do justice, as Allah SWT says in Surah al-Ma'idah verse 8, which means:

"O you who have believed, be persistently standing firm for Allah, witnesses in justice, and do not let the hatred of a people prevent you from being just. Be just; that is nearer to righteousness. And fear Allah; indeed, Allah is Acquainted with what you do.".

Therefore, the principle of tolerance was practised by Prophet PBUH to create a balance of rights and social stability (Nik Mat \& Suradi, 2012). Ab. Majid stated that:

"The practice of tolerance between the Muslim community and the Jews and Christians created a balance of rights and obligations between all parties".

Thus, religious freedom for every citizen was well stipulated in the Medina Charter (Sidik, 2004). According to Al-Mubarakfuri (2011) and Al-Ghazaliy (1997), the Prophet PBUH outlined regulations that embedded the principle of tolerance which was never attempted by other leaders. Mohamad Al-Bakri (2013) asserted his view that:

"Non-Muslims were given religious freedom because Islam recognises human diversity".

Arnold (1913) also agreed that the Prophet PBUH allowed freedom of religion and protected the worship places of Christians and Jews. This principle of tolerance allowed the members of this plural society to instil respect and cooperation. According to Mohamad Al-Bakri (2013), the principle of tolerance is mentioned in Clause 25, which stated:

"And the Jews of Bani 'Auf shall be considered as one political community (Ummah) along with the believers - for the Jews their religion, and for the Muslims theirs, be one client or patron. He, however, who is guilty of oppression or breach of treaty, shall suffer the resultant trouble as also his family, but no one besides".

This Clause is followed by Clauses 26, 27, 28, 29, 30, 31, 32, 33, 34, and 35, which explained the freedom of religion given to non-Muslims. In the Clause, the Jewish tribes were mentioned one by one to explain their role and responsibilities as citizens of Medina. The Jewish tribes that were listed in the Medina Charter are Bani 'Auf, Bani al-Najjar, Bani al-Harith, Bani Saidah, Bani Jusyaim, Bani al-Aus, Bani Tha'labah, Bani Jafnah, and Bani Shutaibah. These Clauses stipulated that the Jews and the Muslim community are together as one ummah. Ab. Majid (2013) argued that the concept of ummah is associated with political cooperation and does not relate to religious matters. The cooperation showed the tolerance of the government when the Islamic country of Medina became the shared land of the multi-religious community instead of the exclusive property of the Muslim community alone (Khan, 2003).

Therefore, Misrawi (2011); Hussin (2003); and Al-Ghazaliy (1997) argued that the Medina Charter is a manifestation of the earnestness of the Prophet PBUH in inculcating the people of Medina to appreciate the principle of tolerance. Non-Muslims were guaranteed not only religious freedom but also guaranteed security and protection. This matter is as explained in surat at-Tawbat verse 4 which means "Excepted are those with whom you made a treaty 
among the polytheists, and then they have not been deficient toward you in anything or supported anyone against you; so complete for them their treaty until their term [has ended]. Indeed, Allah loves the righteous [who fear Him]." and al-Anfal verse 61, which means "And if they incline to peace, then incline to it [also] and rely upon Allah. Indeed, it is He who is the Hearing, the Knowing" (Ibrahim \& El-Qasimy, 1985).

\section{Principle of Love}

According to Al-Buti (1997), a nation is not able to sustain without mutual understanding and unity among members of the society. Therefore, the Medina Charter consists of the principle of love, which shaped the unity of the plural society (Khalid, 1994). This principle is also a source of strength of Medina, as stated by Mohamad Al-Bakri (2013) that:

"The people of Medina are bound by a love so great that they are willing to sacrifice in the name of their brothers."

According to Mohd. Yusoff and Abd. Rahman (2004), there has never been any occurrence in history which depicts the love that grew between the Muhajirin and Ansar. The Muhajirin and Ansar had a close brotherhood to the extent that the Ansar were willing to sacrifice their wealth and lives to the Muhajirin as a sign of love and Islamic brotherhood, as described in the hadith narrated by Abu Hurairah r.a. which means:

"The Ansar said to the Prophet PBUH "Distribute the date palm trees between us and our emigrant brothers." He replied, "No." The Ansar said (to the emigrants), "Look after the trees (water and watch them) and share the fruits with us." The emigrants said, "We listen and obey."

(HR. Bukhari, No. 1132)

The principle of love can be described in the event of the companion of the Prophet PBUH, namely Saad bin Rabi' (Ansar) who was willing to give part of his wealth to Abdul Rahman bin Auf r.a. (Muhajirin). However, Abdul Rahman bin Auf r.a. politely refused the offering and asked Saad bin Rabi' to show the way to the market so that he could engage in trade. Finally, Abdul Rahman bin Auf r.a. became a wealthy and philanthropist (Ahmad Jerlun, 1990) Allah SWT also explains this principle of love in surah al-Hasyr verse 9. Muslim and non-Muslim communities respected and aided each other. The members of this society owned the same rights and position in the Medina Charter. Therefore, Medina became a peaceful and harmonious country (Sungib, 2013). Siddiqi (1982) argued that the reforms carried out by the Prophet PBUH did not include any elements of oppression, rather was inclusive of the values of love and understanding.

Hence, the principle of love is evident in the Medina Charter, as indicated in Clause 15. According to Yaacob (1986), the whole society was obligated to be responsible and work together to protect the weak regardless of race and religion. Denny (1977) claimed that Clause 15 proved the government's scrupulous means because it provided equal protection and assurance from Allah SWT. Clause 15 states:

"And the protection of Allah SWT is one. The humblest of them (believers) can, by extending his protection to anyone, but the obligation on all; and the believers are brothers to one another as against all the people (of the world)".

Furthermore, the principle of love is also mentioned exists in Clause 16. This Clause explains that the Muslim community needs to extend assistance to non-Muslim communities who are 
INTERNATIONAL JOURNAL OF ACADEMIC RESEARCH IN BUSINESS AND SOCIAL SCIENCES Vol. 10, No. 10, 2020, E-ISSN: 2222-6990 @ 2020 HRMARS

in misfortune. According to Ibrahim and El-Qasimy (1985), the Jewish community loyal to the country has the right to welfare. It is not permissible to persecute and oppress them. Clause 16 states:

"And that those who will obey us among the Jews, will have help and equality. Neither shall they be oppressed nor will any help be given against them".

In addition, Clause 18 explains the cooperation that was needed to be done by the plural society when faced with any threats. This Clause proves the presence of love among the society members so that they may express concern for each other. According to Ab. Hamid (2014), the implementation of justice by the Prophet PBUH in the government is a reflection of love towards the plural society. As Clause 18 states:

"And all those detachments that will fight on our side will be relieved by turns". According to Sidik (2004), the principle of love exists in the relationship of the Muslim community, as mentioned in Clause 19. This Clause explains the rights of brotherhood in the Muslim community. Thus, the Muslim community is responsible for defending each other to strengthen the brotherhood. Clause 19 states that:

"And the believers as a body shall take blood vengeance in the way of Allah SWT".

The principle of love embedded in these Clauses built a cooperative relationship in the plural society and built the socio-political stability of Medina, showing how the role of each member of the society recorded in the Medina Charter had a positive effect and thus successfully formed a cooperative relationship in a plural society (Noor, 2010).

\section{Conclusion}

The findings found that Prophet PBUH managed to build good ethnic relations among the people of Medina through the formation of the Medina Charter. The Medina Charter mentions the principles of tolerance and love that are the responsibility of the community to implement it. The appreciation of this principle is in line with the requirements of the Qur'an which educates human beings with noble values. Therefore, the implementation of these principles is important in managing a plural society to form a stable society in terms of socio-politics and the economy. These principles have played a role in uniting and building cooperative relations in a plural society as well as being a defensive fortress of Medina. Therefore, the plural society has become a symbol of strength and success in Medina.

\section{References}

Abdul Rahman, M. S. (1995). Kedudukan Masyarakat Bukan Islam dalam Sejarah Pemerintahan Islam. DIm. Pemerintahan Islam dalam Masyarakat Majmuk. Kuala Lumpur: Institut Kefahaman Islam Malaysia.

Barakat, A. (1979). Muhammad and the Jews. New Delhi: Vikas Publishing House.

Ahmad, Z. A. (1973). Piagam Nabi Muhammad SAW: Konstitusi Negara Bertulis Pertama di Dunia. Jakarta: Bulan Bintang.

Jerlun, A. R. (1990). Rukun Islam Formula PerpaduanUmmah. Kuala Lumpur: Pustaka Al-Mizan.

Al-Bukhary, A. (2009). Terjemahan Hadis Shahih Bukhari Jilid I, II, III \& IV (Terj. H. Zainuddin Hamidy et al.). Kuala Lumpur: Klang Book Centre. 
INTERNATIONAL JOURNAL OF ACADEMIC RESEARCH IN BUSINESS AND SOCIAL SCIENCES

Vol. 10, No. 10, 2020, E-ISSN: 2222-6990 @ 2020 HRMARS

Al-Buti, M. S. R. (1997). Figh Al-Sirah Jilid 2 (Terj. Mohd. Darus Sanawi ‘Ali). Shah Alam: Dewan Pustaka Fajar.

Al-Ghazaliy, M. (1997). Fiqhus Sirah: Menghayati Nilai-Nilai Riwayat Hidup Muhammad Rasulullah SAW (Terj. Abu Laila \& Muhammad Tohir). Klang: Klang Book Centre.

Al-Hamidi, M. A. (2006). Sirah Nabawiyah: Muhammad for the Global Village (Terj. Zulfakar Ali \& Alimin Kuto Al-Madjid). Jakarta: Rabitha Press.

Ali, S. A. H. (1982). Muhammad Rasulullah. The Apostle of Mercy (Terj. Mohiuddin Ahmad). Lucknow, India: Academy of Islamic Research \& Publications.

Al-Mubarakfuri, S. S. A. (2011). Sirah Rasulullah SAW (Terj. Mohd Darus Senawi Ali: Al-Raheeq AlMakhtum). Selangor: Crescent News (K.L) \& Kumpulan Usahawan Muslim.

Al-Siba'ei, M. (1985). Al-Sirah Al-Nabawiyyah (Terj. Nabhan Hussin: Al-Sirah Al-Nabawiyyah Durus Wa'ibar). Shah Alam: Dewan Pustaka Fajar.

Baharuddin, S. A. (Ed.) (2007). Modul Hubungan Etnik. Putrajaya: Universiti Teknologi Mara (UPENA).

Embong, Z. (2016). Ta'awun Piagam Madinah Dalam Pembangunan Komuniti Majmuk di Kawasan

Rukun Tetangga Timur Laut dan Barat Daya, Pulau Pinang. Tesis Doktor Falsafah.Universiti Sains Malaysia. Tidak diterbitkan.

Guillaume, A. (2004). The Life of Muhammad. Karachi: Oxford University Press.

Hamidullah, M. (1968). The Muslim Conduct of the State. Lahore: Ashraf.

Hussin, Z. (2003). Konsep Tasamuh Menurut Perspektif Islam dan Sejarah Penghayatannya. Tesis Sarjana, Universiti Sains Malaysia. Tidak diterbitkan.

Ibn Ishaq. (1970). Sirat Rasulullah (Terj. Alfred Guillaume: The Life of Muhammad). Lahore: Oxford University Press.

Ibnu Khaldun. (1993). Mukadimah Ibn Khaldun (Terj. Dewan Bahasa dan Pustaka). Kuala Lumpur: Dewan Bahasa dan Pustaka.

Ibrahim, A., \& El-Qasimy, D. (1985). Piagam Madinah: Pandangan dan Ulasan (Terj. Abu Bakar Hamzah). Kuala Lumpur: Gelanggang Kreatif.

Izzuddin. (2008). Konsep Ummah dalam Piagam Madinah. Jurnal Darussalam, 7(2), 109-122.

Khairuddin, A. (2007). Konstitusi Madinah Latar Belakang dan Dampak Sosialnya. Al-Banjari, 5(9), 120.

Noor, M. R. (2010). Meneladani Sejarah Umat Islam dalam Membentuk Masyarakat Hadhari yang Gemilang Abad ke 21. Jurnal Hadhari, 2(2), 19-40.

Nik Mat, N. A. A. \& Suradi, A. H. A. H. (2012). Muhammad bukan Nasionalis: Ajaran Nabi Muhammad Melintasi Sempadan Negara dan Bangsa. Selangor: Kemilau Publika.

Peters, F. E. (1994). Muhammad and the Origins of Islam. New York: State University of New York Press.

Pulungan, J. S. (1993). Prinsip-Prinsip dalam Perlembagaan Madinah ditinjau dari Pandangan AlQur'an. Disertasi Doktor Falsafah, IAIN Syarif Hidayatullah Jakarta.

Rahman, A. (1992). Ensiklopedia Sirah, Sunah, Dakwah dan Islam Jilid 1(Terj. Zaharah Salleh: Muhammad S.A.W. Encyclopaedia of Seerah, Volume 1). Kuala Lumpur: Dewan Bahasa dan Pustaka.

Ramadhan, M. (1991). Inti sari Seerah Muhammad bin Abdullah SAW. Kuala Lumpur: A.S Noordeen.

Siddiqi, N. (1982). Muhammad Membentuk Ummah (Terj. Mustaffa Ramadhan: Muhammad the Benefactory of Humanity). Pulau Pinang: Concentration Book Centre.

Sosrodirdjo, H. R. M. (1988). Ensiklopedia Istilah Agama Islam. Kuala Lumpur: Golden Books Centre. 
INTERNATIONAL JOURNAL OF ACADEMIC RESEARCH IN BUSINESS AND SOCIAL SCIENCES Vol. 10, No. 10, 2020, E-ISSN: 2222-6990 @ 2020 HRMARS

Sungib, S. (2013). Rahsia-Rahsia Besar disebalik Sirah Rasulullah SAW. Selangor: Kemilau Publika. Watt, W. M. (1956). Muhammad at Medina. London: Oxford University Press.

Yaacob, A. M. (1986). Hak Asasi Manusia Menurut Islam: Sejarah dan Konsepnya. Bangi: Universiti Kebangsaan Malaysia.

\section{List of Interviews}

Interview with Ab. Majid, M. Z. at the Department of Figh and Usul Fiqh, Kulliyyah IImu Wahyu dan Sains Manusia, IIUM, Gombak on 30 January 2013, at 11.30 am.

Interview with Mohamad Al-Bakri, Z. at the Cahaya Kasturi Library Office, Putra Nilai, Nilai, Negeri Sembilan on 29 January 2013, at 9.30 am.

Interview with Zainal Abidin, D. at Syifa' Clinic, Penang on 17 September 2015, at 6.00 pm. 